\title{
ECLECTIC ARCHITECTURE ON MASJID PUSDAI BUILDING IN BANDUNG
}

\author{
${ }^{1}$ Tamara Florenza. ${ }^{2}$ Dr. Ir. Bachtiar Fauzy, MT. \\ ${ }^{1}$ Student in the Bachelor's (S-1) Study Program in Architecture \\ at Parahyangan Catholic University \\ ${ }^{2}$ Senior lecturer in the Bachelor's (S-1) Study Program in Architecture \\ at Parahyangan Catholic University
}

\begin{abstract}
Eclectic architecture is a product of globalization in which architectural styles from different places and time intertwine each other. The development of eclectic architecture in Indonesia tends to follow the trend, neglecting the local value. A study towards eclectic architecture is necessary to raise society's concern towards the identification of foreign and local architectural style. Masjid PUSDAI Bandung is selected as a research object to represent these issues above, in which the architectural style of Spain, Indian, and Javanese mosque intertwined each other.
\end{abstract}

The research's purpose towards the research object as a representation of eclectic architecture is to define the meaning of eclectic architecture in Masjid PUSDAI as well as to understand the form of eclecticism in Masjid PUSDAI. The eclectic architecture form will be analyzed towards the mixture of Indian, Spain, and Javanese mosque architecture style.

Literature study as a theoretical base consist of the main theories such as the theory of eclectic architecture and theory of form and technic, as well as the supporting theories such as the architecture of Spain, Indian, and Javanese mosque. A comparative-qualitative approach is used as research method. This method compares the documentation from building observation with the literature theories for a further analysis.

Through this research it can be concluded that the eclectic architecture form of Masjid PUSDAI Bandung is seen through mixture of two to three architecture style among its elements, thus forming a new architecture style. However, the intertwinement of architecture style doesn't show on several elements. Some of them show an identical form which is used in Indian, Spain, and Javanese mosque.

This research is expected to educate readers, architecture students, and experts in academic fileds, about how to execute the eclectic architecture design in public facilities, especially on mosques in Indonesia.

Keywords: eclectic, architecture, mosque

\section{ARSITEKTUR EKLEKTIK PADA BANGUNAN MASJID PUSDAI DI BANDUNG}

\author{
${ }^{1}$ Tamara Florenza. ${ }^{2}$ Dr. Ir. Bachtiar Fauzy, MT. \\ ${ }^{1}$ Mahasiswa S1 Program Studi Arsitektur Universitas Katolik Parahyangan. \\ ${ }^{2}$ Dosen Pembimbing S1 Program Studi Arsitektur Universitas Katolik Parahyangan
}

\begin{abstract}
Abstrak- Arsitektur eklektik merupakan salah satu gaya arsitektur yang muncul akibat globalisasi di mana gaya arsitektur dari berbagai lokasi dan zaman bercampur. Dalam perkembangannya di Indonesia, arsitektur eklektik seringkali didesain mengikuti tren yang berlaku tanpa memperhatikan unsur tradisi. Pentingnya studi arsitektur eklektik diangkat agar masyarakat lebih sensitif terhadap identifikasi gaya arsitektur yang bercampur antara yang asing dan lokal. Masjid PUSDAI Bandung diambil menjadi objek penelitian sebagai representasi dari isu yang
\end{abstract}

${ }^{1}$ Corresponding Author: tmr_flo@hotmail.com 
diangkat, di mana bangunan mengalami percampuran gaya arsitektur masjid pendatang seperti masjid India dan Spanyol serta arsitektur lokal masjid Jawa.

Penelitian terhadap objek penelitian sebagai representasi dari arsitektur eklektik bertujuan untuk mengetahui arti arsitektur eklektik pada Masjid PUSDAI serta memahami wujud arsitektur eklektik yang diterapkan pada bangunan Masjid PUSDAI. Wujud arsitektur eklektik ditinjau berdasarkan percampuran antara gaya arsitektur masjid India, Spanyol, dan Jawa.

Studi literatur yang diambil sebagai landasan teori dalam penelitian berangkat dari teori utama seperti teori arsitektur eklektik dan teori bentuk dan teknik serta teori pendukung seperti teori arsitektur masjid Spanyol, masjid India, dan arsitektur masjid Jawa. Metode penelitian yang diambil berupa pendekatan komparatif-kualitatif di mana observasi bangunan di lapangan didokumentasikan dalam foto-foto dan dibandingkan dengan teori-teori para ahli untuk dianalisis lebih lanjut.

Melalui penelitian ditemukan bahwa wujud arsitektur eklektik pada Masjid PUSDAI di Bandung terlihat melalui percampuran antara dua hingga tiga gaya arsitektur di dalam elemen-elemennya sehingga menciptakan langgam arsitektur yang baru. Namun, pada beberapa elemen arsitektur percampuran gaya tidak tampak, tetapi lebih menonjolkan bentuk yang dipakai secara umum baik oleh masjid di India, Spanyol, maupun Jawa.

Kata-kata kunci: arsitektur, eklektik, masjid

\section{PENDAHULUAN}

\subsection{LATAR BELAKANG PENELITIAN}

Kemajuan bidang ilmu pengetahuan dan teknologi memberi pengaruh besar terhadap perkembangan arsitektur di Indonesia. Revolusi industri yang muncul di Eropa pada abad ke19 berkembang pesat dan melahirkan material baru seperti baja yang dapat mempermudah pengerjaan konstruksi bangunan. Modernisasi yang lebih mementingkan efektivitas bangunan menyebabkan dihilangkannya elemen ragam hias serta penyederhanaan bentuk bangunan. Padahal, tiap daerah memiliki ciri khasnya masing-masing, terlebih lagi di Indonesia yang kaya akan tradisi dan budaya. Globalisasi juga mempermudah akses informasi sehingga memungkinkan gaya arsitektur asing masuk dan mempengaruhi arsitektur tradisional.

Arsitektur di Indonesia tidak luput dari perkembangannya di era post modern di mana berbagai gaya arsitektur muncul sebagai tanggapan terhadap arsitektur modern. Tanggapan tersebut terlihat dengan mengembalikan unsur historis dan nilai-nilai lokal pada bangunan. Salah satu contoh gaya arsitektur yang muncul adalah arsitektur eklektik yang mencampurkan gaya arsitektur dari berbagai masa dengan mengambil unsur-unsur yang dianggap terbaik, baik unsur lokal maupun non-lokal. Melalui percampuran gaya tersebut, arsitektur eklektik seringkali menciptakan sebuah langgam yang baru.

Arsitektur eklektik memberi pengaruh terhadap perkembangan arsitektur di kota-kota besar di Indonesia, contohnya Kota Bandung. Arsitektur eklektik yang masuk dan berkembang di Kota Bandung antara lain terlihat dari bangunan-bangunan ibadah yang masuk lewat ajaran agama. Percampuran gaya tersebut terlihat melalui perpaduan unsur keagamaan, unsur budaya tempat asal bangunan tersebut berkembang, serta penyesuaiannya dengan konteks lokal. Pentingnya studi arsitektur eklektik diangkat agar masyarakat lebih sensitif terhadap identifikasi gaya arsitektur yang bercampur antara yang asing dan lokal.

Arsitektur masjid diambil sebagai salah satu contoh bangunan ibadah yang berkembang di Kota Bandung serta memiliki beragam gaya arsitektur, dari gaya arsitektur lokal maupun non-lokal. Arsitektur masjid berkembang di Bandung seiring dengan masuknya ajaran Islam yang semula berkembang di area Timur Tengah, yaitu di Arab, kemudian meluas hingga ke barat dan timur, contohnya ke benua Eropa dan Asia. Islam meluas hingga ke Indonesia dan masuk lewat daerah pesisir Jawa Timur hingga ke Jawa Barat.

Percampuran gaya dalam arsitektur masjid ditinjau dari gaya arsitektur masjid yang masuk dan berkembang di Indonesia. Pertama, yaitu adanya pengaruh kuat dari arsitektur 
masjid India yang masuk lewat jalur perdagangan dan jalur sutra dari pesisir Jawa Timur. Kedua, yaitu adanya pengaruh arsitektur masjid Spanyol yang masuk lewat kolonialisme di Indonesia. Selain itu, arsitektur masjid Jawa yang memiliki perkembangan yang kuat di Indonesia juga memberi pengaruh terhadap perkembangan arsitektur masjid di Bandung. Maka, studi kasus yang diambil adalah arsitektur masjid di India, Spanyol, dan Jawa.

Dalam penelitian ini, objek yang diambil sebagai contoh representatif terhadap isu yang dijabarkan di atas adalah Masjid PUSDAI di Bandung. Masjid mengadopsi unsur lokalitas berupa arsitektur Jawa, namun bentuk keseluruhan diinterpretasikan kembali ke dalam langgam modern dengan pengaruh arsitektur masjid asing. Wujud arsitektur eklektik dalam Masjid PUSDAI akan diteliti lebih lanjut melalui pemilahan elemen-elemen bangunannya serta kaitannya terhadap arsitektur masjid India, arsitektur masjid Spanyol, dan arsitektur masjid Jawa yang mempengaruhi bentuk keseluruhan masjid.

\subsection{PERUMUSAN MASALAH}

Melalui fenomena yang telah dijabarkan, berikut adalah rumusan masalah dan kriteria pemilihan objek dan studi kasus yang diangkat dalam penelitian.

a) Arsitektur eklektik dikaji berdasarkan percampuran gaya arsitektur masjid India yang masuk ke Indonesia lewat jalur perdagangan, arsitektur masjid Spanyol yang masuk lewat kolonialisme, dan arsitektur masjid Jawa yang memiliki perkembangan yang kuat di Indonesia. Ketiganya tampak pada elemen fisik bangunan Masjid PUSDAI Bandung.

b) Studi kasus sebagai objek pembanding diambil berdasarkan objek yang representatif terhadap masa kejayaan arsitektur masjid di India, Spanyol, dan Jawa, yaitu Masjid Jami Srinagar, Masjid Agung Kordoba, dan Masjid Agung Demak.

c)

\subsection{PERTANYAAN PENELITIAN}

Berdasarkan isu dan latar belakang yang tertera di atas, maka berikut ini merupakan pertanyaan yang menjadi lingkup bahasan kajian penelitian:

a) Apa yang dimaksud dengan arsitektur eklektik pada penelitian ini?

b) Bagaimana wujud arsitektur eklektik pada bangunan Masjid PUSDAI di Bandung?

\section{KAJIAN TEORI}

\subsection{PENGERTIAN ARSITEKTUR EKLEKTIK}

\subsubsection{PENGERTIAN EKLEKTIK}

Pengertian eklektik secara etimologis dapat berarti menyeleksi, tidak menerima sesuatu yang bersifat diskriminasi. Eklektik menurut Kamus Besar Bahasa Indonesia memiliki arti bersifat memilih yang terbaik dari berbagai sumber (tentang orang, gaya, metode). Dalam Webster's New World Dictionary \& Thesaurus eklektik adalah penyeleksian dari beragam sistem, doktrin, dan sumber. Sementara itu dalam Oxford English Dictionary (1989) eklektik berarti selektif atau menyeleksi (Harisah, 2007:5). Dengan demikian dapat dikatakan bahwa pengertian eklektik secara umum adalah pemilihan atau seleksi dari gaya-gaya yang telah ada sebelumnya untuk membentuk suatu gaya yang baru.

\subsubsection{ARSITEKTUR EKLEKTIK}

Dalam sejarah arsitektur istilah eklektisisme dipakai sebagai penanda percampuran gaya arsitektur yang menyeleksi gaya dari berbagai masa yang dianggap memiliki unsur terbaik (Harisah, 2007:46). Gaya arsitektur memiliki definisi yaitu tampilan bangunan yang ditunjukkan secara konsisten melalui komposisi pembentuknya. Seiring dengan perkembangan 
zaman, gaya arsitektur terus berkembang dan beradaptasi hingga menjadi sebuah rangkaian kronologis yang memiliki nilai historis. Sementara itu, percampuran gaya arsitektur merupakan penggabungan berbagai gaya arsitektur sehingga menciptakan sebuah gaya yang baru.

Arsitektur eklektik muncul di Eropa pada abad 19 sebagai tanggapan terhadap kejenuhan yang terjadi di masyarakat akan bentuk dan konsep arsitektur klasik. Era Renaissance dianggap sebagai titik awal munculnya arsitektur eklektik di mana unsur-unsur arsitektur Romawi kembali dipakai dan dicampurkan dengan gaya arsitektur lain hingga menghasilkan gaya baru seperti arsitektur Neo-Gotik dan Neo-Klasik (Sumalyo, 1997:24).

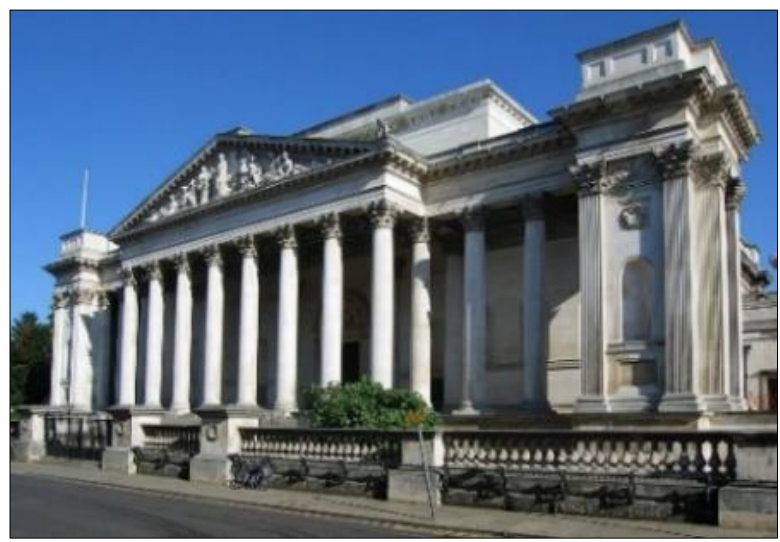

Figur 1. Arsitektur Neo-Klasik Museum Fitzwilliam (Sumber: Wikipedia, 2017)

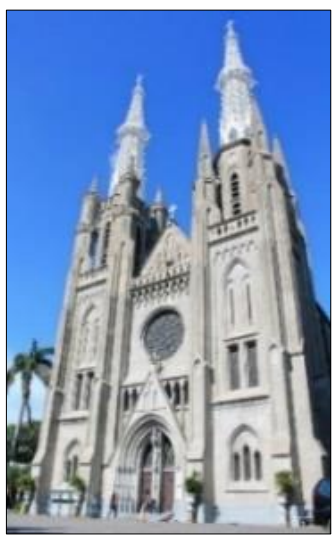

Figur 2. Arsitektur Neo-Gotik Gereja Kathedral Jakarta

(Sumber: www.kratonpedia.com, 2017)

Berdasarkan uraian tersebut, maka dapat dikatakan bahwa arsitektur eklektik merupakan percampuran gaya arsitektur yang didasari oleh proses penyeleksian dari berbagai gaya arsitektur berbagai masa yang dianggap memiliki unsur yang terbaik. Arsitektur eklektik terbentuk dari kejenuhan terhadap arsitektur tradisional, sehingga melalui percampuran gaya tercipta wujud dan langgam yang baru.

\subsection{TEORI BENTUK DAN TEKNIK}

Secara garis besar, teori bentuk dan teknik dapat membantu untuk menganalisis gaya arsitektur dengan cara membedah bangunan ke dalam setiap elemen secara detail. Elemen bentuk dilihat melalui tata ruang, pelingkup, serta permukaan bangunan. Sementara itu elemen keteknikan dilihat melalui struktur dan material bangunan. Pada penelitian ini, percampuran gaya arsitektur ditinjau melalui bentuk yang terdiri dari aspek tata ruang, pelingkup, dan permukaan bangunan, serta keteknikan yang terdiri dari aspek material untuk membedah elemen-elemen pada bangunan.

Bentuk dalam arsitektur dapat dilihat melalui elemen-elemen bagian yang membentuk bangunan secara keseluruhan, yaitu mass, space, dan surface (Schulz, 1968:131). Contohnya adalah bentuk geometris, seperti bulat, persegi, segitiga, dan kombinasinya. Bentuk tersebut disusun hingga membentuk tatanan ruang-ruang yang ada di dalamnya. Keteknikan dalam bangunan merupakan peran material dan konstruksi yang melekat pada arsitektur dalam memenuhi fungsinya (Schulz, 1968:161). Keseluruhan konstruksi bangunan terlihat pada pondasi, dinding, lantai, langit-langit, pintu, dan jendela. Sementara itu, material terlihat dari pada pelingkup, konstruksi, hingga ornamen bangunan. 


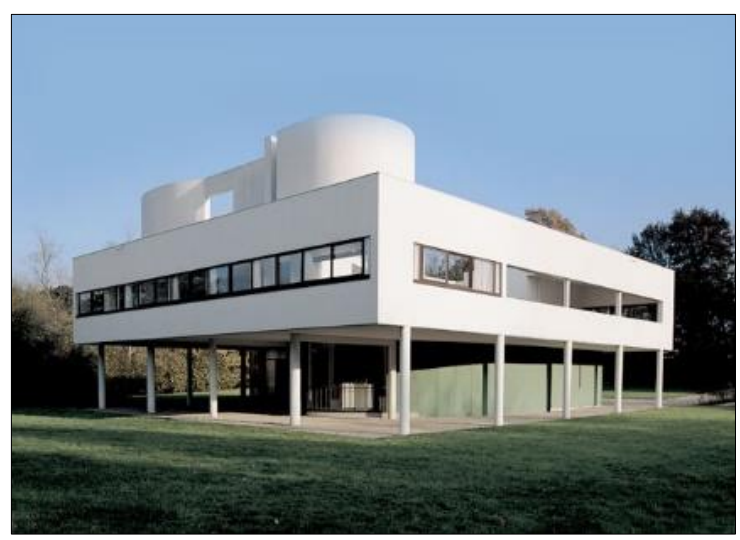

Figur 3. Bentuk

(Sumber: www.shaneinda04.wordpress.com, 2017)

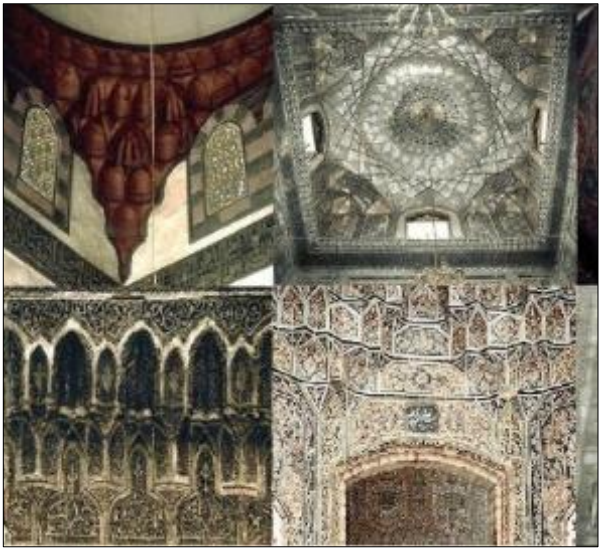

Figur 4. Material

(Sumber: www.keywordsking.com, 2017)

\subsection{ARSITEKTUR MASJID}

Ajaran Islam semula berkembang di Arab. Seiring dengan perkembangan zaman, ajaran tersebut menyebar ke negara-negara di Timur mulai dari Mesopotamia, Persia, Turki, Irak, Iran hingga daerah sungai Indus. Sementara itu penyebarannya ke negara-negara barat antara lain ke negara Spanyol dan Marokko. Ajaran meluas ke benua lain seperti Eropa dan Afrika, hingga ke Cina dan Asia Tenggara (Sumalyo,2006:4).

Masuknya ajaran Islam ke Nusantara dikemukakan melalui berbagai macam teori. Penyebaran Islam yang dipercaya masuk ke Nusantara melalui jalur perdagangan dinyatakan dalam teori Gujarat, teori Mekkah, dan teori Persia (Hidayatullah, 2013: 8-9). Teori serupa dinyatakan oleh Graaf mengenai pengaruh India terhadap arsitektur masjid Nusantara. Teori lain dikemukakan Wirjosuparto bahwa arsitektur masjid berasal dari arsitektur pendopo di Jawa. Hal tersebut terlihat dari denah arsitektur masjid Nusantara yang berbentuk bujur sangkar serta bentuk atap tumpang yang menyerupai atap rumah joglo.

Bentuk masjid melalui perkembangan zaman telah menyesuaikan budaya lokal serta keperluan penggunanya. Sementara itu, penyebaran Islam melalui jalur sutra bergerak dari Timur Tengah hingga ke Eropa dan Asia. Masuknya ajaran Islam ke Nusantara dapat berasal dari Arab, Persia, maupun India. Pada penelitian ini arsitektur masjid dikaji berdasarkan pengaruh asing yang masuk ke Nusantara, terutama melalui pengaruh India dan Spanyol, serta adaptasinya dengan arsitektur masjid lokal Jawa.

\subsubsection{ARSITEKTUR MASJID INDIA}

Arsitektur masjid di India, dalam contoh kasus studi Masjid Jami Srinagar, memiliki karakteristik berupa bentuk massa yang ramping dan penataan yang konsentris, tata ruang hypostyle berbentuk bujur sangkar dengan elemen iwan dan area lapangan di tengah, memiliki bentuk atap tumpang dengan puncak yang runcing, pelingkup dinding berupa iwan lateral dengan elemen lengkung pointed arc, serta pelingkup bawah berupa peninggian lantai sebagai penanda batas suci. Elemen onamen yang dipakai berupa corak arabesque, geometri, dan kaligrafi, dan corbel. Material menggunakan konstruksi kayu pada rangka atap, kolom, dan ornamen, material batu bata sebagai elemen lengkung, serta material batu sebagai pelat lantai dan umpak kolom. 


\subsubsection{ARSITEKTUR MASJID SPANYOL}

Arsitektur masjid Spanyol dalam kasus studi Masjid Agung Kordoba, memiliki karakteristik berupa bentuk massa yang masif dengan tata massa linear, tata ruang hypostyle dengan denah persegi atau persegi panjang. Atap masjid berbentuk pelana dan rib vault dome, pelingkup tengah berupa barisan kolom dan horseshoe arc, peninggian lantai sebagai penanda batas suci, serta ornamen berupa corak islam. Material bangunan menggunakan batu dan batu bata pada pelingkup dan konstruksi serta dinding mosaik pada mihrab.

\subsubsection{ARSITEKTUR MASJID JAWA}

Arsitektur masjid Jawa memiliki karakteristik sebagai berikut. Bentuk dan tata ruang masjid berupa denah persegi atau persegi panjang dengan penonjolan pada bagian mihrab, di mana denah persegi lebih banyak digunakan pada masjid Jawa Tengah dan Jawa Timur, sementara denah persegi panjang lebih banyak dipakai pada masjid Jawa Barat. Pelingkup atas berupa atap tumpang bertingkat dua hingga lima, pelingkup tengah berupa dinding, dinding terbuka, dan struktur saka guru, serta peninggian lantai sebagai peralihan ke batas suci.

Ornamen yang digunakan berupa corak floral, kaligrafi, alam, dan binatang khas Jawa yang kebanyakan menggunakan material kayu. Corak floral biasa dominan digunakan pada masjid Jawa dengan Sementara itu, material bangunan menggunakan kayu sebagai ornamen, kolom, dan saka guru yang menopang rangka atap tumpang, serta batu bata pada pelingkup dinding bangunan.

Tabel 1. Kesimpulan Arsitektur Masjid India, Spanyol, dan jawa

\begin{tabular}{|c|c|c|c|c|}
\hline \multirow{2}{*}{ No } & \multirow{2}{*}{ Elemen } & \multicolumn{3}{|c|}{ Teori Arsitektur } \\
\hline & & Masjid India & Masjid Spanyol & Masjid Jawa \\
\hline 1 & $\begin{array}{l}\text { Bentuk } \\
\text { dan Tata } \\
\text { Ruang }\end{array}$ & $\begin{array}{l}\text { Bentuk ruang berupa } \\
\text { denah hypostyle dengan } \\
\text { jajaran kolom, di mana } \\
\text { proporsi shalat lebih } \\
\text { kecil disbanding area } \\
\text { lapangan. Terdapat } i \text { - } \\
\text { wan, mihrab, ruang } \\
\text { shalat, lapangan, dan } \\
\text { wudhu }\end{array}$ & $\begin{array}{l}\text { Bentuk ruang berupa } \\
\text { denah hypostyle } \\
\text { dengan jajaran kolom, } \\
\text { di mana proporsi area } \\
\text { lapangan seimbang } \\
\text { dengan area shalat. } \\
\text { Terdapat mihrab, } \\
\text { ruang shalat, lapangan, } \\
\text { dan wudhu }\end{array}$ & $\begin{array}{l}\text { Denah ruang biasa } \\
\text { berbentuk persegi } \\
\text { maupun persegi } \\
\text { panjang dengan } \\
\text { mihrab sebagai } \\
\text { penunjuk arah kiblat }\end{array}$ \\
\hline 2 & $\begin{array}{c}\text { Pelingkup } \\
\text { Atas }\end{array}$ & $\begin{array}{l}\text { Memakai atap kubah } \\
\text { pada umumnya. Di } \\
\text { Srinagar memakai atap } \\
\text { tumpang dengan } \\
\text { puncak runcing. }\end{array}$ & $\begin{array}{l}\text { Atap masjid Spanyol } \\
\text { menggunakan bentuk } \\
\text { atap kubah rib vault } \\
\text { dan pelana. }\end{array}$ & $\begin{array}{l}\text { Atap masjid } \\
\text { mengambil bentuk } \\
\text { atap tumpang yang } \\
\text { terdiri dari } 3 \text { susun }\end{array}$ \\
\hline 3 & $\begin{array}{l}\text { Pelingkup } \\
\text { Tengah }\end{array}$ & $\begin{array}{l}\text { Terdapat barisan kolom } \\
\text { serta } i \text {-wan gerbang dan } \\
\text { dinding dengan bentuk } \\
\text { pelengkung pointed } \\
\text { arc. }\end{array}$ & $\begin{array}{l}\text { Terdapat barisan } \\
\text { kolom dan dinding } \\
\text { dengan bentuk } \\
\text { pelengkung horseshoe } \\
\text { arc. }\end{array}$ & $\begin{array}{l}\text { Terdapat tiang soko } \\
\text { guru, dinding, pintu, } \\
\text { dan jendela sebagai } \\
\text { pelingkup ruang, } \\
\text { maupun dinding } \\
\text { terbuka. }\end{array}$ \\
\hline 4 & $\begin{array}{c}\text { Pelingkup } \\
\text { Bawah }\end{array}$ & $\begin{array}{l}\text { Lantai ditinggikan, } \\
\text { merupakan penanda } \\
\text { peralihan antara ruang } \\
\text { profan dan area suci }\end{array}$ & $\begin{array}{l}\text { Lantai ditinggikan, } \\
\text { merupakan penanda } \\
\text { peralihan antara ruang } \\
\text { profan dan area suci }\end{array}$ & $\begin{array}{l}\text { Lantai ditinggikan, } \\
\text { merupakan penanda } \\
\text { peralihan antara } \\
\text { ruang profan dan } \\
\text { area suci }\end{array}$ \\
\hline
\end{tabular}




\begin{tabular}{clll}
\hline \multirow{5}{*}{ Ornamen } & $\begin{array}{l}\text { Menggunakan motif } \\
\text { arabesque, kaligrafi, } \\
\text { dan pola geometri, } \\
\text { corbel, dan ornament } \\
\text { floral pengaruh Hindu. }\end{array}$ & $\begin{array}{l}\text { Menggunakan motif } \\
\text { arabesque, kaligrafi, } \\
\text { dan pola geometri. } \\
\text { Motif geometri paling } \\
\text { dominan digunakan. }\end{array}$ & $\begin{array}{l}\text { Ornamen dominan } \\
\text { memakai motif } \\
\text { floral seperti lung- } \\
\text { lungan, wajikan, } \\
\text { serta motif alam dan } \\
\text { kaligrafi. }\end{array}$ \\
\hline \multirow{5}{*}{ Material } & $\begin{array}{l}\text { Menggunakan material } \\
\text { kayu sebagai kolom, } \\
\text { rangka atap, plafond, } \\
\text { dan ornamen, serta } \\
\text { material batu pada } \\
\text { dinding dan elemen } \\
\text { lengkung. }\end{array}$ & $\begin{array}{l}\text { Memakai material } \\
\text { batu dan bata pada } \\
\text { elemen lengkung, } \\
\text { atap, dinding, dan } \\
\text { lantai, serta batu } \\
\text { mosaik pada dinding } \\
\text { mihrab. }\end{array}$ & $\begin{array}{l}\text { Material kayu } \\
\text { sebagai konstruksi } \\
\text { dan ornamen, } \\
\text { keramik sebagai } \\
\text { ornamen, serta bata } \\
\text { sebagai pelingkup. }\end{array}$ \\
\hline
\end{tabular}

\section{METODA PENELITIAN}

Jenis metode penelitian yang digunakan dalam proses analisis dapat beragam sesuai dengan kebutuhan dan kesesuaiannya untuk menjawab pertanyaan-pertanyaan dan permasalahan yang dikemukakan. Metode penelitian yang dipakai antara lain adalah metode kualitatif-komparatif, yaitu seperti sebagai berikut:

a) Metode Kualitatif, yaitu metode penelitian yang berangkat dari data, observasi, fenomena, serta fakta-fakta yang terjadi di lapangan. Teori-teori dari para ahli digunakan sebagai acuan untuk mengarahkan penelitian sesuai dengan isu yang terjadi di lapangan. Kasus-kasus yang terjadi kemudian ditelaah satu per satu untuk mempelajari sifatnya yang berbeda satu sama dengan yang lain sehingga hasil akhir penelitian bersifat kualitatif, bukan berupa data kuantitas.

b) Metode Komparatif, yaitu metode yang membandingkan fenomena dan keadaan fisik objek di lapangan dengan studi objek yang diambil dari pustaka berdasarkan dokumentasi, gambar-gambar, dan foto-foto hasil observasi di lapangan. Wujud masjid PUSDAI di Bandung dikaji berdasarkan aspek bentuk dan tata ruang, pelingkup atas, pelingkup tengah, pelingkup bawah, elemen ornamen, serta material bangunan. Aspekaspek tersebut dibandingkan dengan aspek-aspek yang sama yang terdapat dalam arsitektur masjid India, Spanyol, dan Jawa hingga terlihat wujud percampuran gaya yang terjadi dalam bangunan Masjid PUSDAI di Bandung.

\section{ANALISA}

\subsection{ARSITEKTUR EKLEKTIK PADA BANGUNAN MASJID PUSDAI DI} BANDUNG

\subsubsection{TATA MASSA DAN TATA RUANG}

Tata ruang pada Masjid PUSDAI dibandingkan dengan tata ruang pada majid di India, yaitu Masjid Jami Srinagar. Pada Masjid Jami Srinagar di India ruang shalat utama memiliki proporsi yang lebih kecil dibandingkan dengan area lapangan. Sementara itu, Masjid PUSDAI memiliki proporsi area shalat yang seimbang dengan area lapangan. Ruang shalat Masjid PUSDAI memiliki denah hypostyle, serupa dengan tatanan masjid Jami Srinagar, tapi perbedaannya adalah barisan kolom dalam ruang masjid tersebut tidak dilengkapi dengan elemen lengkung. Adapun perbedaan antara $i$-wan Masjid PUSDAI dengan $i$-wan gerbang pada arsitektur masjid India adalah jumlahnya yang hanya terdiri dari tiga buah gerbang, yaitu di depan serta samping kiri dan kanan masjid. 
Tata ruang dalam Masjid PUSDAI dibandingkan dengan tata ruang pada Masjid Agung Kordoba sebagai berikut. Denah Masjid PUSDAI berbentuk persegi panjang disertai dengan jajaran kolom dan elemen lengkung atau disebut juga hypostyle, sama seperti tata ruang Masjid Agung Kordoba. Ruang shalat pada Masjid PUSDAI memiliki proporsi yang lebih seimbang dengan area lapangannya, di mana area lapangan terletak di depan ruang shalat, sama seperti proporsi dan tatanan pada Masjid Agung Kordoba. Selain itu, adanya $i$-wan lateral yang mengelilingi area lapangan pada Masjid PUSDAI juga serupa dengan area lapangan pada Masjid Agung Kordoba yang dikelilingi $i$-wan lateral berbentuk denah U.

Adapun perbandingan antara tata ruang Masjid PUSDAI dengan masjid di Jawa adalah sebagai berikut. Denah ruang shalat Masjid PUSDAI Bandung yang berbentuk persegi panjang serupa dengan denah ruang shalat pada masjid di Jawa. Namun, berbeda dari Masjid PUSDAI yang memiliki orientasi yang jelas ke Kiblat, pada masjid Jawa terdapat kesan ambigu dengan adanya empat tiang soko guru di tengah sehingga orientasi masjid terkesan konsentris. Hal tersebut bertentangan dengan kaidah Islam yang mengharuskan orientasi masjid ke kiblat.

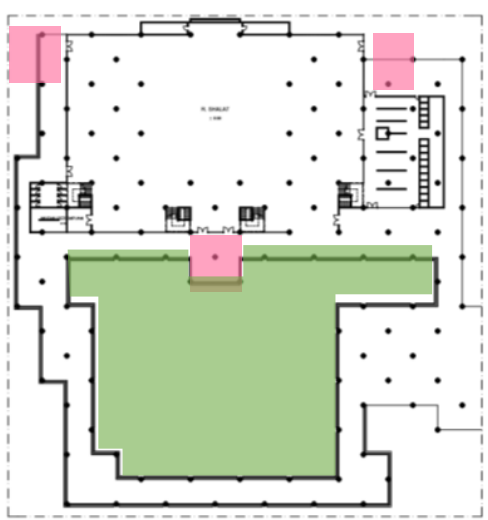

Figur 5. Tata Ruang pada Masjid PUSDAI di Bandung

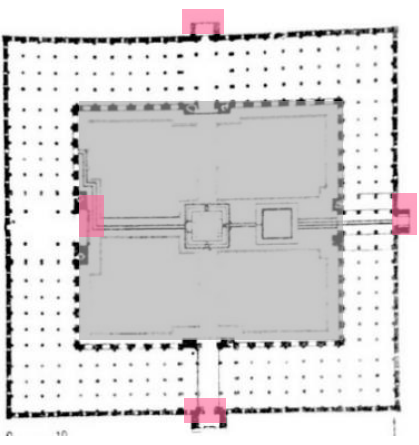

Figur 6. Tata Ruang pada Masjid Jami Srinagar di India

(Sumber: Burckhardt, 2009) 


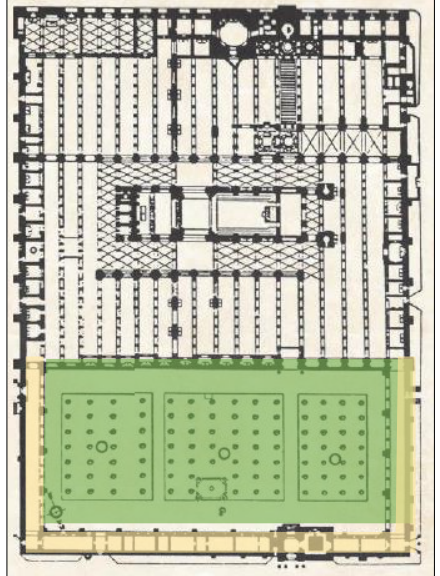

Figur 7. Denah Lantai Masjid Agung Kordoba

(Sumber: Burckhardt, 2009)

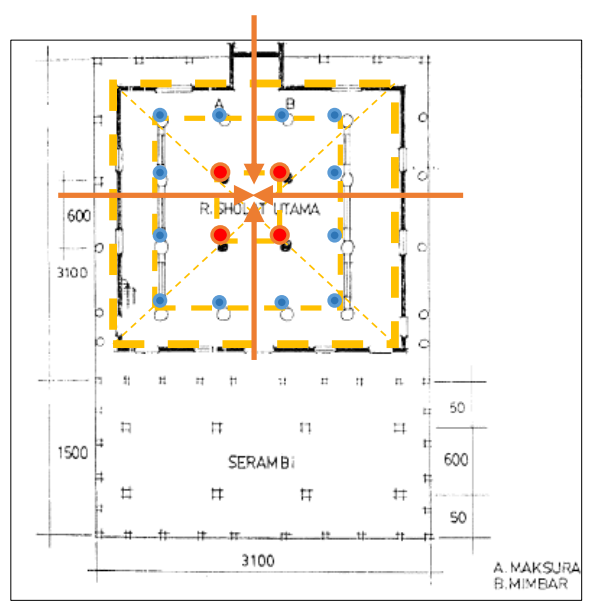

Figur 8. Denah Masjid Agung Demak (Sumber: http://wftr-120294.blogspot.co.id/, 2017)

Secara keseluruhan, tata ruang pada arsitektur Masjid PUSDAI lebih dominan diwujudkan dalam bentuk yang mengadaptasi tata ruang pada masjid Spanyol dibandingkan masjid India. Hal tersebut ditunjukkan melalui denah hypostyle dengan proporsi ruang, terutama antara ruang shalat dan area lapangan, yang serupa dengan Masjid Agung Kordoba. Percampuran gaya ditunjukkan dengan mengadopsi elemen $i w a n$ gerbang sebagai penanda area masuk yang merupakan pengaruh dari arsitektur India serta adanya hierarki yang terasa pada bagian tengah ruang shalat seperti pada masjid-masjid di Jawa.

\subsubsection{PELINGKUP BANGUNAN}

Elemen pelingkup bangunan pada Masjid PUSDAI di Bandung dibagi menjadi pelingkup atas, tengah, dan bawah. Pelingkup atas ditandai dengan gubahan atap dan plafond, pelingkup tengah ditandai dengan penggunaan dinding serta elemen kolom dan lengkung, serta pelingkup bawah yang ditandai dengan elemen lantai.

Pelingkup atas Masjid PUSDAI dibandingkan dengan masjid-masjid di India, Spanyol, dan Jawa. Berikut adalah perbandingan atap masjid dengan masjid Jawa. Jumlah tumpang pada masjid-masjid di Jawa pada umumnya terdiri dari dua hingga lima tumpuk. Tiap tumpuk pada masjid Jawa memiliki maknanya masing-masing, yaitu syariat dan hakekat. Berbeda dari masjid Jawa, bentuk atap tumpang pada Masjid PUSDAI tidak sepenuhnya mengadopsi bentuk atap tumpang pada masjid Jawa, tetapi dimodifikasi menjadi bentuk yang modern di mana atap tumpang terdiri dari empat tumpuk dengan rotasi pada tiap tumpuknya.

Adapun perbandingannya dengan Masjid Jami Srinagar adalah sebagai berikut. Masjid Jami Srinagar memiliki $i$-wan pada area shalat dengan bentuk atap tumpang yang terpengaruh ajaran Hindu-Buddha. Atap tumpang pada masjid tersebut teridiri dari dua tumpuk sementara pada Masjid PUSDAI atap tumpang terdiri dari empat tumpuk. Puncak atap Masjid Jami Srinagar berbentuk runcing, sedangkan puncak atap pada Masjid PUSDAI cenderung landai karena telah disesuaikan dengan iklim tropis di Indonesia.

Perbandingan atap Masjid PUSDAI dengan atap Masjid Agung Kordoba di Spanyol antara lain sebagai berikut. Atap pada Masjid PUSDAI yang berbentuk tumpang memiliki bentuk yang berbeda dibandingkan dengan atap rib vault dome yang terdapat pada Masjid Agung Kordoba. Adapun atap penunjang pada Masjid PUSDAI yang dijejer menggunakan 
bentuk atap limas, berbeda dari bentuk atap penunjang Masjid Agung Kordoba yang berupa atap pelana. Dengan demikian, dapat dikatakan bahwa bentuk atap pada Masjid PUSDAI tidak mengambil unsur atap Masjid Agung Kordoba di Spanyol.

Berdasarkan uraian tersebut, dapat dikatakan bahwa pelingkup atap mengadopsi gaya arsitektur India dengan wujud atap tumpang yang diadaptasikan kembali ke dalam konteks lokalnya, yaitu iklim tropis di Jawa Barat sehingga puncak atap tumpang berbentuk lebih landai, seperti yang terlihat pada atap masjid-masjid tradisional Jawa. Bentuk atap juga dimodifikasi lebih lanjut untuk menunjukkan inovasi di era arsitektur modern dengan menggunakan teknik konstruksi dan bahan yang lebih canggih, yaitu dengan adanya konstruksi bentang lebar dan gubahan atap yang dirotasi di tiap tumpuknya.

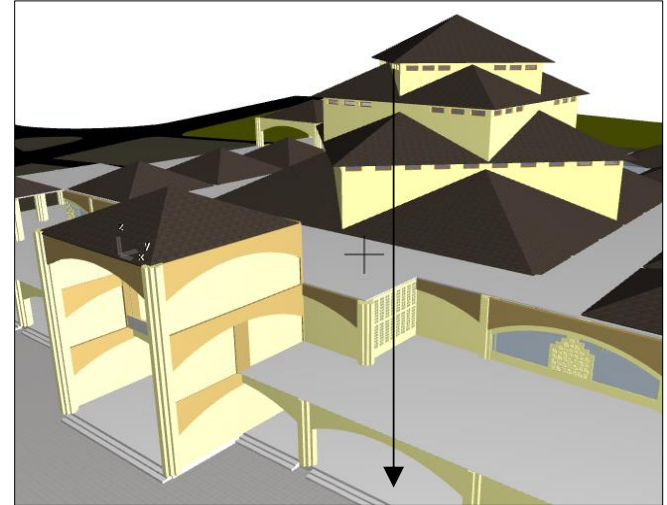

Atap Tumpang Bertingkat Empat

Figur 9. Atap Tumpang pada Masjid PUSDAI

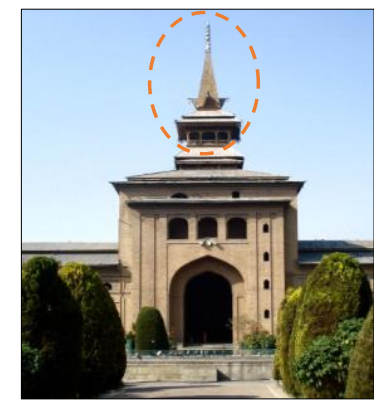

Figur 11. Atap Tumpang Masjid Jami Srinagar (Sumber: http://travel.kashmironline.net/, 2017)

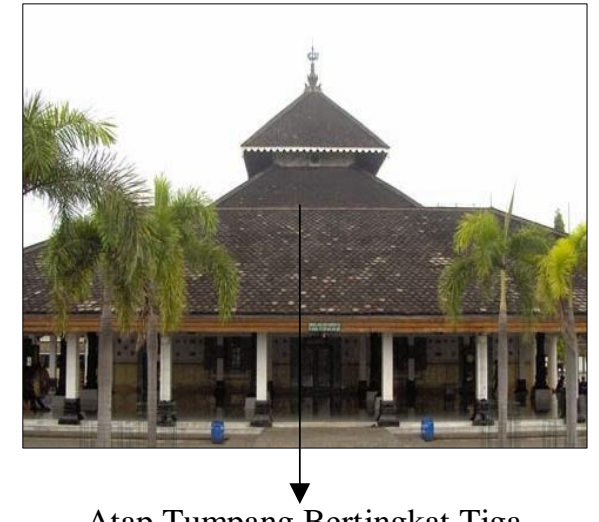

Atap Tumpang Bertingkat Tiga

Figur 10. Atap Tumpang Masjid Agung Demak

(Sumber: Wikipedia, 2017)

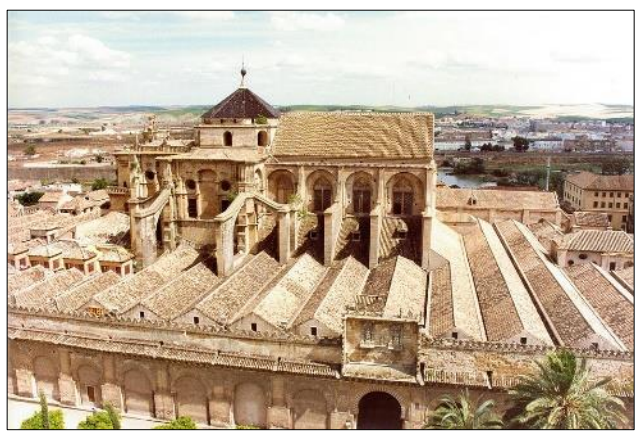

Figur 12. Atap Masjid Agung Kordoba (Sumber: Wikimedia, 2017)

Adapun pelingkup tengah masjid dibandingkan dengan pelingkup tengah pada masjid di India, Spanyol, dan Jawa. Barisan kolom dan arcade atau disebut juga elemen lengkung yang membentang di dalam dan di sekeliling ruang shalat Masjid PUSDAI memiliki kesamaan dengan Masjid Agung Kordoba. Namun, berbeda dari masjid tersebut, barisan kolom dan elemen lengkung yang ditemukan pada Masjid PUSDAI tidak menutupi pandangan pada area 
tengah ruang shalat. Struktur bentang lebar pada bagian atap memungkinkan ruangan bebas kolom pada area tersebut.

Berdasarkan bentuknya, elemen lengkung yang ditemukan pada Masjid PUSDAI di Bandung berupa lengkung semisirkular yang dibuat patah pada sambungannya dengan elemen vertikal kolom. Bentuk tersebut diadaptasikan dari bentuk elemen lengkung horseshoe pada Masjid Agung Kordoba di Spanyol yang juga dibuat patah pada sambungan antara elemen lengkung dengan kolom serta bentuk elemen lengkung semisirkular pada fasad luar Masjid Agung Kordoba. Perbedaannya adalah bentuk lengkung pada Masjid Agung Kordoba yang dibuat bertingkat dua dan berbentuk lebih dari setengah lingkaran. Selain itu, bentang elemen lengkung pada Masjid PUSDAI lebih besar karena telah mengadopsi teknologi modern.

Perbandingan antara pelingkup tengah Masjid PUSDAI dan Masjid Jami Srinagar di India dapat dilihat melalui bentuk elemen lengkung serta fasad bangunan. Bentuk elemen lengkung pada Masjid PUSDAI berupa lengkung semisirkular dengan bentang yang lebar, sementara bentuk elemen lengkung pada Masjid Jami Srinagar berupa lengkung pointed arc dan hanya digunakan pada dinding luar masjid. Fasad pada Masjid Jami Srinagar dan Masjid PUSDAI memiliki kemiripan, yaitu dengan menggunakan elemen lengkung sebagai dinding terbuka yang membentuk fasad eksterior masjid. Selain itu, elemen lengkung pada bagian $i$ wan gerbang Masjid Jami Srinagar dan Masjid PUSDAI dibuat dengan proporsi yang lebih tinggi dibandingkan elemen lengkung lainnya untuk menunjukkan pintu masuk ruang shalat.

Adapun perbandingan antara pelingkup tengah Masjid PUSDAI dengan masjid di Jawa adalah sebagai berikut. Elemen lengkung yang terdapat pada Masjid PUSDAI tidak ditemukan dalam masjid di Jawa. Struktur keempat soko guru yang berada di tengah ruang shalat pada masjid di Jawa, contohnya adalah Masjid Agung Demak, berbeda dari struktur pada Masjid PUSDAI yang memakai struktur bentang lebar. Fasad Masjid Agung Demak merupakan salah satu contoh masjid di Jawa yang dahulu menggunakan barisan kolom sebagai pembatas ruang shalat dan serambi. Namun, sekarang fasad ruang shalat masjid telah ditutup dengan dinding masif dan bukaan berupa jendela. Fasad tersebut serupa dengan fasad yang diterapkan pada Masjid PUSDAI di mana ruang shalat dikelilingi dengan dinding masif dan bukaan jendela, sementara area sirkulasi di depan dibatasi dengan barisan kolom dan elemen lengkung.

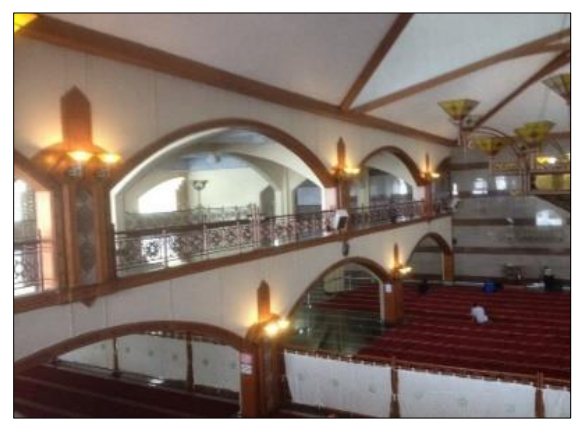

Figur 13. Elemen Lengkung Masjid PUSDAI

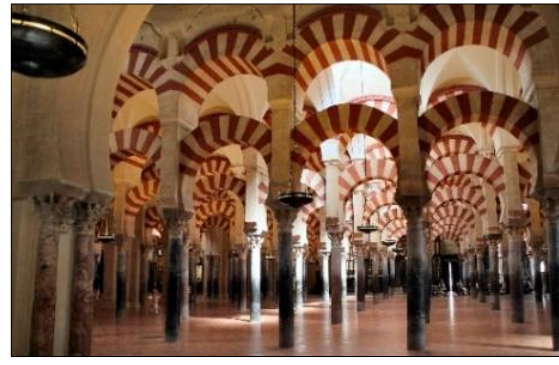

Figur 14. Horseshoe Arc Masjid Agung Kordoba (Sumber: www.4gress.com, 2017) 


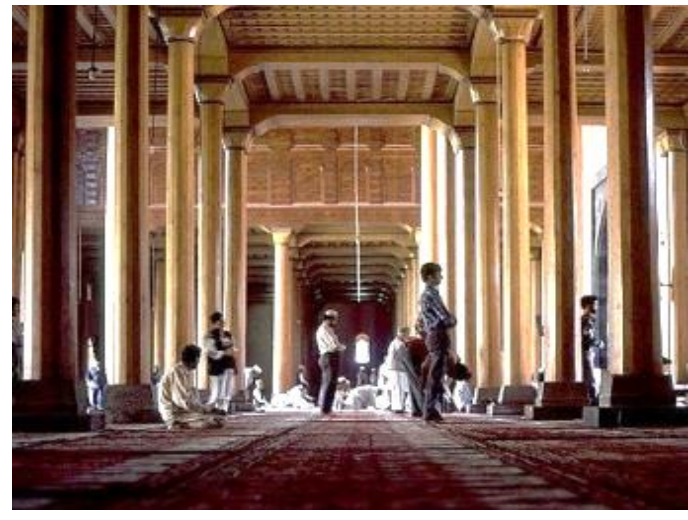

Figur 15. Ruang Dalam Masjid Jami Srinagar (Sumber: http://www.kashmirhills.com/, 2017)

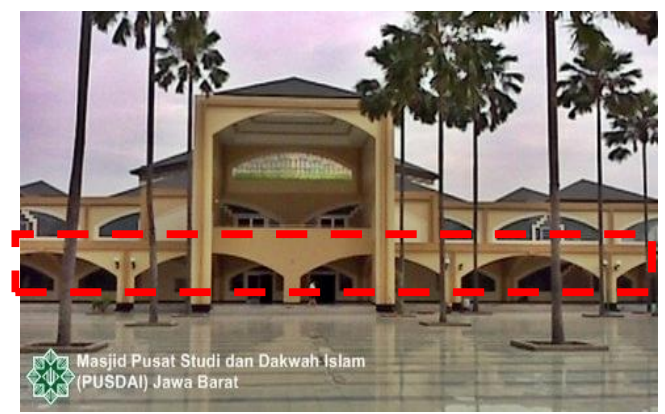

Elemen lengkung sebagai dinding terbuka pada sirkulasi di depan ruang shalat

Figur 17. Fasad Masjid PUSDAI (Sumber: Wikimapia, 2017)

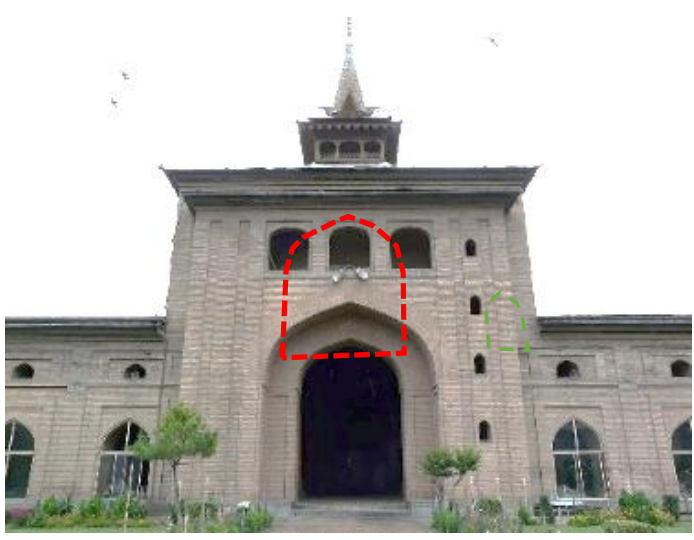

Proporsi elemen lengkung pointed arc yang berbeda pada iwan gerbang dan iwan lateral

Figur 16. Elemen Lengkung Masjid Jami Srinagar

(Sumber: http://www.findmessages.com/, 2017)

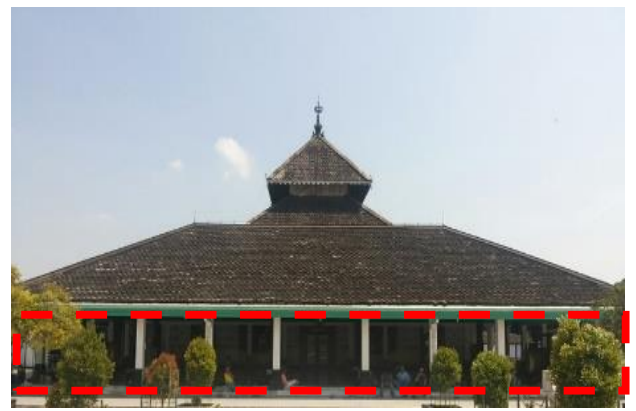

Barisan kolom yang mengelilingi serambi masjid membentuk fasad bangunan

Figur 18. Fasad Masjid Agung Demak (Sumber: Wikipedia, 2017)

Berdasarkan uraian tersebut, dapat dikatakan bahwa pelingkup tengah Masjid PUSDAI mengambil bentuk lengkung yang serupa dengan elemen lengkung pada Masjid Agung Kordoba di Spanyol, yaitu elemen lengkung semisirkular. Hanya saja proporsi bentang elemen lengkung pada Masjid PUSDAI dibuat lebih lebar dengan adanya teknologi konstruksi di era modern. Adapun fasad bangunan masjid yang terdiri dari dinding lengkung terbuka menyerupai fasad terbuka pada masjid India dan masjid Jawa.

Pelingkup bawah yang merupakan elemen lantai pada Masjid PUSDAI Bandung berupa peninggian dari area sekitarnya sebanyak tiga undakan, yaitu setinggi $42 \mathrm{~cm}$, yang menandai peralihan ruang profan dan area suci bangunan yang dimulai dari area selasar di sekeliling ruang shalat. Peninggian lantai pada Masjid PUSDAI telah menggunakan undakan yang melekat pada tanah. Konsep yang berbeda diterapkan pada masjid-masjid tradisional di Jawa yang menggunakan umpak sehingga lantai masjid diangkat dari tanah di bawahnya. Namun, seiring dengan perkembangan zaman, bentuk tersebut digantikan dengan peninggian lantai yang menempel pada tanah, seperti yang terlihat pada objek penelitian. Dengan kata lain, 
peninggian lantai bangunan sebagai peralihan antara ruang profan dan batas suci telah mengkuti kaidah Islam pada umumnya yang dipakai baik pada masjid di India, Spanyol, maupun di Jawa.

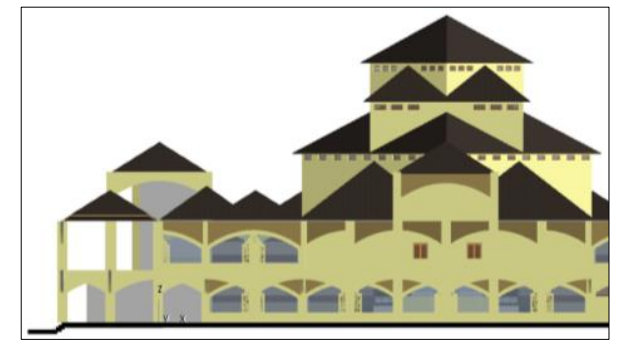

Figur 19. Lantai Masjid PUSDAI

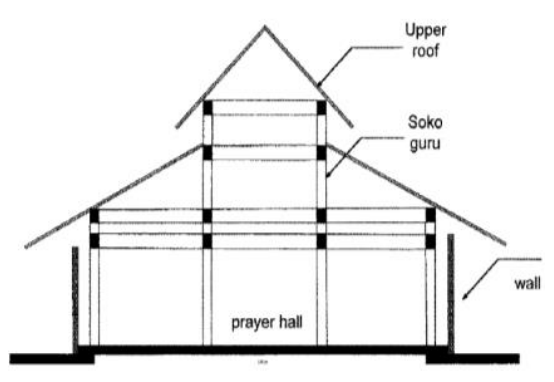

Figur 20. Lantai Masjid Jawa (Sumber: Bambang Setia Budi, 2017)

\subsubsection{ELEMEN ORNAMEN}

Ornamen dengan corak geometris paling dominan digunakan dalam Masjid PUSDAI. Corak tersebut terlihat pada railing tangga, motif di jendela kaca, jendela kerawang, dan ukiran kayu di dinding ruang shalat serta dinding mimbar. Pola geometris yang terlihat pada jendela kaca dan kerawang berupa pengulangan pola oktagon dan pola rosette yang disusun secara berseling, serta pola eight pointed star yang terlihat pada railing tangga dan dinding mihrab. Pola oktagon rosette dan eight pointed star tersebut memiliki kesamaan dengan pola geometris seperti yang terlihat pada dinding masjid-masjid di India dan Spanyol. Dominannya penggunaan ornamen dengan pola geometri menyerupai ornamen yang dipakai pada arsitektur Masjid Agung Kordoba dan Masjid Jami Srinagar yang menggunakan ornamen corak Islam.

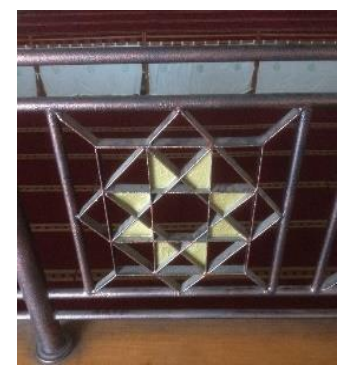

Figur 21. Pola Eight Pointed Star Masjid PUSDAI

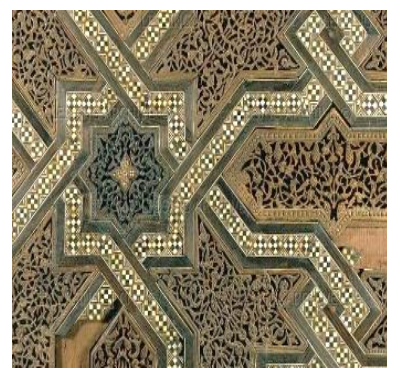

Figur 22. Corak Eight Pointed Star pada Masjid Kutubbiya

(Sumber: http://islamicarts.org/2012/, 2017)

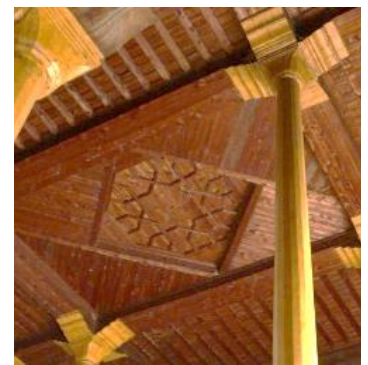

Figur 23. Corak Eight Pointed Star pada Masjid Jami Srinagar

(Sumber: http://islamic-arts.org/, 2017) 
Corak floral yang digunakan pada Masjid PUSDAI diterapkan pada dinding mihrab dengan material kayu yang dikombinasikan dengan corak geometri bintang dan segi enam. Ukiran floral yang dibuat meliuk-liuk dan spiral tersebut dilekatkan pada dinding mihrab serta lis-lis pada kolom bangunan yang menghadap bagian tengah ruang shalat. Bentuk ukiran floral pada Masjid PUSDAI diambil dari corak iluminasi dengan motif-motif tradisional yang terdapat dalam Mushaf Sundawi. Corak tersebut mengangkat unsur tanaman di Jawa Barat, contohnya antara lain adalah bunga teh, tanaman melati, gandaria, dan patrakomala.

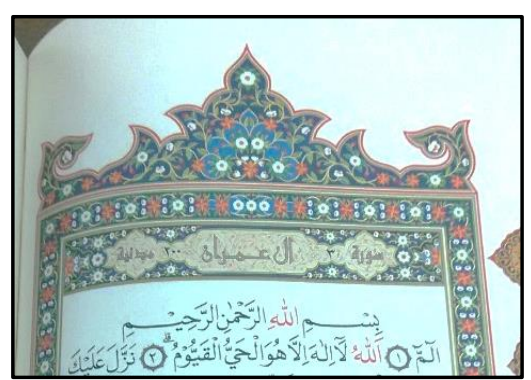

Figur 24. Corak Bunga Teh pada Mushaf Sundawi

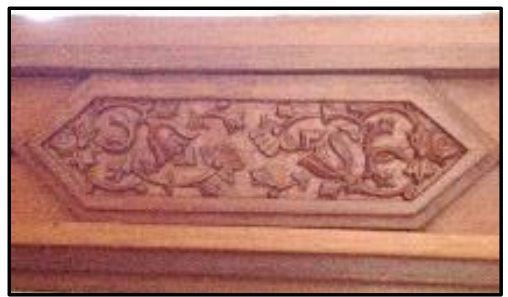

Figur 25. Corak Bunga Teh pada Masjid PUSDAI

Bila dibandingkan, penggunaan corak floral pada Masjid PUSDAI berbeda dari corak arabesque yang banyak digunakan pada masjid-masjid di India dan Spanyol. Corak floral dalam perkembangan masjid-masjid di Jawa Barat tidak memiliki budaya yang cukup kuat, kecuali pada masjid-masjid di Jawa Tengah dan Jawa Timur yang mengambil corak IslamJawa, contohnya adalah corak Lung-lungan pada Masjid Gedhe Kauman. Adapun corak yang dipengaruhi budaya Hindu-Jawa biasa menggunakan motif bunga teratai, contohnya seperti pada Masjid Agung Cirebon.

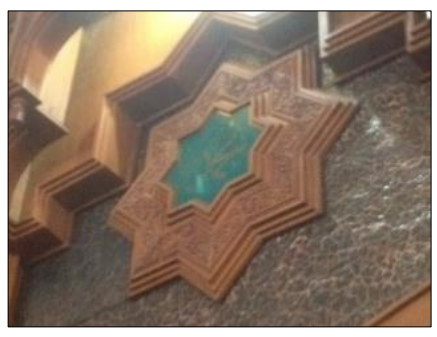

Figur 26. Kayu pada Ornamen Geometris Masjid PUSDAI Bandung

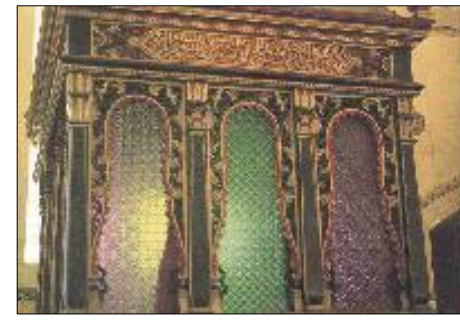

Figur 27. Kayu Corak Kaligrafi Masjid Agung Demak (Sumber: Wikipedia, 2017)

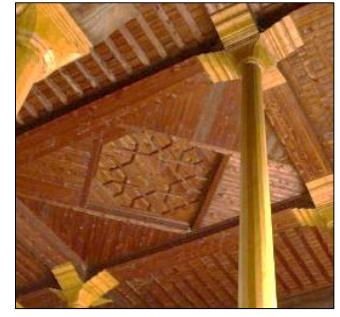

Figur 28. Ornamen Kayu Masjid Jami Srinagar

(Sumber:

https://sarsonkekhet.in/, 2017)

Elemen ornamen pada Masjid PUSDAI menggunakan corak yang mengambil unsur corak Islam serta corak ornamen masjid Jawa Barat. Hal tersebut ditunjukkan melalui corak geometri yang serupa dengan ornamen seni Islam, contohnya seperti pola oktagonal yang digunakan pada dinding, jendela, dan railing pada masjid serta corak kaligrafi yang digunakan pada dinding mihrab. Corak floral pada Masjid PUSDAI diambil dari Mushaf Sundawi yang mengangkat corak khas Jawa Barat seperti tanaman gandaria dan patrakomala. Corak tersebut 
kemudian diadaptasikan kembali dengan ornamen-ornamen masjid Jawa, serupa dengan ornamen lung-lungan pada Masjid Jawa.

Corak kaligrafi yang digunakan dalam Masjid PUSDAI serupa dengan corak kaligrafi yang diambil pada masjid-masjid pada umumnya, contohnya adalah masjid di Spanyol, India, dan Jawa. Selain itu, seperti pada Masjid PUSDAI, letak corak kaligrafi pada dinding mihrab juga terlihat dalam masjid-masjid tersebut. Dinding mihrab dipakai sebagai permukaan tempat meletakkan corak kaligrafi untuk mempermudah penyampaian makna dari ayat-ayat Al-Quran terhadap umat yang sedang melakukan kegiatan ibadah di ruang shalat.

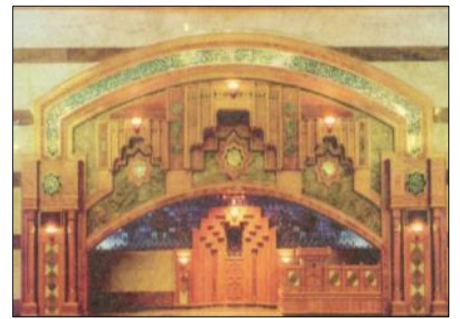

Figur 29. Corak Kaligrafi pada Kayu Mihrab Masjid PUSDAI

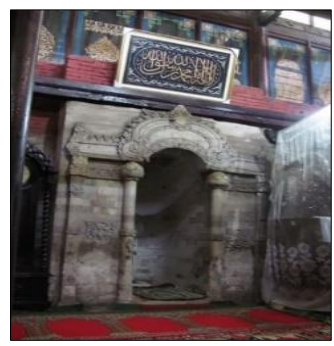

Figur 31. Corak Kaligrafi pada Dinding Mihrab Masjid Agung Banten

(Sumber: www.ngobrol.indosat.com, 2017)

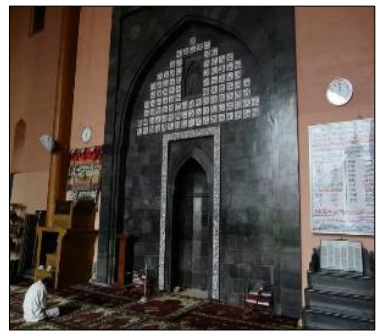

Figur 30. Corak Kaligrafi pada Dinding Mihrab Masjid Jami Srinagar

(Sumber: www.sarsonkekhet.in, 2017)

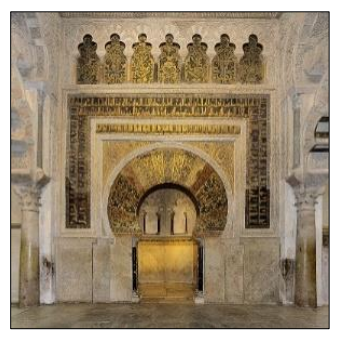

Figur 32. Corak Kaligrafi pada Dinding Mihrab Masjid Agung Kordoba (Sumber: Burckhardt, 2009)

\subsubsection{MATERIAL}

Material pada Masjid PUSDAI menggunakan material konvensional dan modern. Material modern ditunjukkan melalui konstruksi dan fasad bangunan seperti material beton pada kolom, elemen lengkung, dan balok, baja pada struktur atap, serta kaca dan kaca patri pada dinding masjid. Material konvensional berupa batu bata dan kayu digunakan pada dinding dan ornamen masjid. Pada dinding mihrab digunakan kombinasi material yang memberi tampilan serupa dengan Masjid Agung Kordoba. Ornamen lebih banyak menggunakan ukiran kayu sebagai perwujudan tradisi lokal yang serupa dengan ukiran kayu pada ornamen masjid di Jawa. 


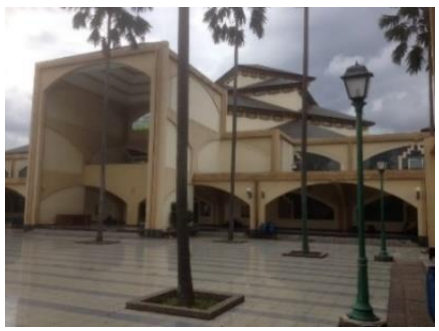

Figur 33. Material Batu Bata pada Dinding Masjid PUSDAI

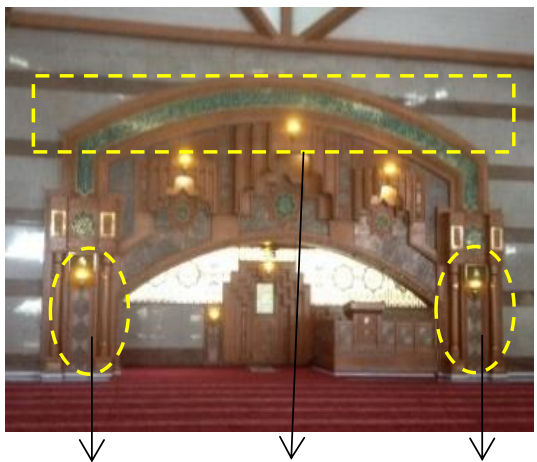

Corak Kaligrafi, floral, dan geometri pada berbagai material seperti kayu, tembaga, granit, dan kaca

Figur 35. Dinding Mihrab pada Masjid PUSDAI Bandung

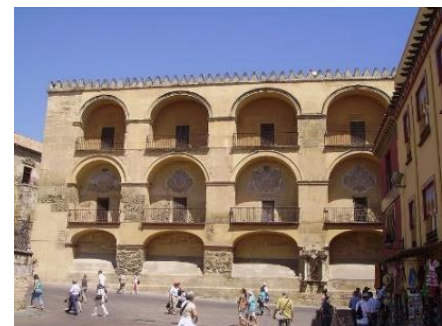

Figur 34. Material Batu Bata pada Dinding Masjid Agung Kordoba (Sumber: Wikimedia, 2017)

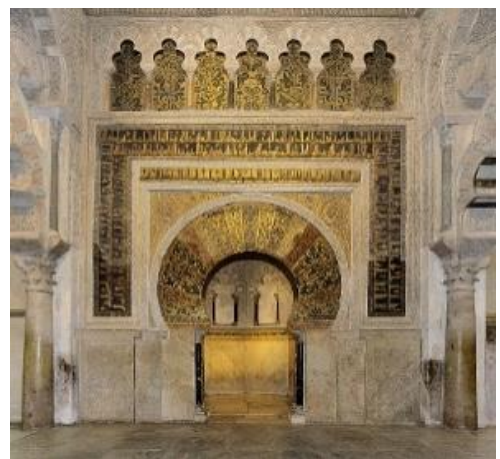

Corak Kaligrafi dan Arabesque pada material batu mosaic dan marmer

Figur 36. Dinding Mihrab pada Masjid Agung Kordoba

(Sumber: Burckhardt, 2009)

\subsection{TEMUAN}

Melalui penelitian yang dilakukan terdapat beberapa temuan mengenai wujud arsitektur eklektik pada Masjid PUSDAI di Bandung. Pertama, corak Mushaf Sundawi yang ditemukan pada ornamen di bagian mihrab dan lis kolom membuktikan bahwa corak Sunda juga digunakan sebagai elemen arsitektur dalam masjid di Jawa Barat. Kedua, penggunaan material beton dan baja pada konstruksi bangunan merupakan wujud perkembangan teknologi dalam arsitektur modern. Ketiga, modifikasi bentuk atap masjid yang dibuat berotasi dan bertingkat empat serta penataan massa yang modular merupakan pengaruh arsitektur modern yang menciptakan inovasi dari bentuk masjid tradisional.

\section{KESIMPULAN}

Arsitektur eklektik berarti arsitektur yang menyeleksi gaya-gaya arsitektur dari berbagai masa yang dianggap terbaik. Seleksi gaya tersebut dapat mengambil seluruh maupun sebagian unsur dari elemen-elemen bangunan yang dianggap merepresentasikan gaya arsitektur pada zamannya. Dalam penelitian ini, arsitektur eklektik diterapkan melalui percampuran gaya antara arsitektur masjid Spanyol, masjid India, dan masjid Jawa yang 
dipadukan dengan penggunaan teknologi modern. Percampuran gaya arsitektur dilakukan dengan mengambil wujud elemen bangunan yang serupa pada gaya-gaya arsitektur tersebut yang diterapkan pada elemen-elemen bangunan Masjid PUSDAI sehingga membentuk suatu langgam arsitektur baru.

Wujud arsitektur eklektik pada Masjid PUSDAI di Bandung terlihat melalui percampuran antara dua hingga tiga gaya arsitektur di dalam dan di antara elemen-elemennya sehingga menciptakan gubahan langgam elemen arsitektur yang baru. Namun, pada beberapa elemen arsitektur percampuran gaya tidak tampak, tetapi lebih menonjolkan bentuk yang dipakai secara umum baik oleh masjid di India, Spanyol, maupun Jawa.

Contoh dari percampuran gaya tersebut antara lain adalah tata massa dan tata ruang yang mencampurkan unsur arsitektur masjid India, Spanyol, dan Jawa, pelingkup tengah yang menggabungkan bentuk pelingkup tengah pada masjid Spanyol dan Jawa, bentuk atap yang mengadaptasikan bentuk atap masjid India ke dalam masjid Jawa sebagai wujud adaptasi konteks lokal, ornamen yang mengambil corak Islamic Art dan ornamen Jawa, serta material yang menggunakan bahan konvensional seperti pada masjid Spanyol, India, dan Jawa, maupun material modern.

\subsection{SARAN}

Penelitian yang membahas arsitektur eklektik ini merupakan topik yang menarik untuk diangkat agar pembaca maupun peneliti lebih sensitif terhadap nilai-nilai historis yang terkandung dalam gaya arsitektur terdahulu di tengah kemajuan zaman modern ini. Dalam kasus objek studi ini, Masjid PUSDAI diangkat sebagai representasi wujud arsitektur eklektik yang mencampurkan gaya arsitektur asing seperti masjid Spanyol dan India serta arsitektur masjid lokal Jawa Barat. Dalam perancangan arsitektur eklektik seorang arsitek diharapkan agar lebih peduli terhadap nilai-nilai tradisi lokal, yaitu dengan memasukkan unsur lokal yang memiliki nilai tradisi dan budaya setempat dibandingkan memasukkan unsur-unsur asing demi nilai estetika semata maupun mengikuti tren yang berkembang pada zaman tersebut.

Adanya berbagai keterbatasan menyebabkan penelitian ini masih belum sempurna. Maka dari itu, penelitian tentang arsitektur eklektik pada Masjid PUSDAI di Bandung ini dapat disempurnakan melalui pendalaman teori-teori yang diambil serta jumlah studi objek yang dijadikan contoh untuk membandingkan arsitektur objek dengan arsitektur masjid di Spanyol, India, dan Jawa Barat. Penelitian mengenai arsitektur eklektik sebagai sebuah pencampuran gaya pada Masjid PUSDAI di Bandung dapat digali lebih dalam pada penelitian serupa berikutnya.

\section{DAFTAR PUSAKA}

Budi, Bambang Setia. (2004). A study on the history and development of the javanese mosque Part I. Journal of Asian Architecture and Building Engineering, Vol. 3 No. 1, 189-195.

Budi, Bambang Setia. (2005). A study on the history and development of the javanese mosque Part II. Journal of Asian Architecture and Building Engineering, Vol. 4 No. 1, 1-8.

Budi, Bambang Setia. (2006). A study on the history and development of the javanese mosque Part III. Journal of Asian Architecture and Building Engineering, Vol. 5 No. 2, 229-236.

Burckhardt, Titus. (2009). Art of Islam, Language and Meaning. Bloomington: World Wisdom, Inc.

Ching, D.K. (2000). Arsitektur: Bentuk, Ruang, dan Tatanan. Jakarta: Erlangga.

Departemen Pendidikan dan Kebudayaan. (1984). Arsitektur Tradisional Daerah Jawa Barat.

Dodds, Jerrilynn D. (Ed). (2004). Al-Andalus the Art of Islamic Spain. New York: Harry N. Abrams, Inc. 
Frishman, Martin, Hasan-Uddin Khan, Mohammad Al-Asad. (1994). The Mosque: History, Architectural Development \& Regional Diversity. New York: Thames \& Hudson.

Handinoto dan Samuel Hartono. (2007). Pengaruh pertukangan cina pada bangunan masjid kuno di jawa abad 15-16. Dimensi Teknik Arsitektur, Vol. 35 No.1, 23-40.

Harisah, Afifah, Sudaryono Sastrosasmito, dan Adi Utomo Hatmoko. (2007). Eklektisisme dan Arsitektur Eklektik: Prinsip dan Konsep Desain. Yogyakarta: Gadjah Mada University Press.

Hidayatullah, Muhammad Syarif. (2013). Teori-teori masuknya islam ke wilayah timur indonesia. Jurnal Ilmiah Non-Seminar, 1-15.

Hildebrand, Tracy. (2012). Architectural origins of the mosque of cordoba. Nebraska Anthropologist, Paper 175, 6-14.

Hussain, Nazakat. (2015). Islamic architecture of muslim rule in kashmir: a study of some mosques and their architectural styles and preservation. International Journal of Multidisciplinary Research and Development, Vol. 2 Issue 9, 4-7.

Jencks, Charles. (1977). The Language of Post-Modern Architecture. London: Academy Edition.

Jencks, Charles. (1982). Architecture Today. London: Academy Edition.

Norberg-Schulz, Christian. (1968). Intentions in Architecture. MIT Press.

Pemerintah Provinsi Daerah Tingkat I Jawa Barat. (1990). Pusat Da'wah Islam (PUSDAI) Jawa Barat.

Pusat Dakwah Islam. (n.d.). Diakses tanggal 22 Februari 2017, dari http://pusdai.or.id/pusdai/pusatdakwah-islam/

Rochym, Abdul. (1983). Sejarah Arsitektur Islam: Sebuah Tinjauan. Bandung: Angkasa.

Rochym, Abdul. (1983). Mesjid dalam Karya Arsitektur Nasional Indonesia. Bandung: Angkasa.

Salura, Purnama. (2010). Arsitektur yang Membodohkan. Bandung: CSS Publishing.

Soeroto, Myrtha. (2011). Pustaka Budaya \& Arsitektur Jawa. Yogyakarta: Myrtle Publishing.

Sumalyo, Yulianto. (1997). Arsitektur Modern Akhir Abad XIX dan Abad XX. Yogyakarta: Gadjah Mada University Press.

Sumalyo, Yulianto. (2006). Arsitektur Mesjid dan Monumen Sejarah Muslim. UGM Press: Yogyakarta.

Szostak, John D. (n.d.) The Spread of Islam Along the Silk Road. Diakses tanggal 3 Maret 2017, dari https://depts.washington.edu/silkroad/exhibit/religion/islam/islam.html

Vinansyah, Ghia Gusdiawan. (2014). Diakses tanggal 5 Maret 2017, dari http://informasimasalalu.blogspot.co.id/2014/02/jalur-sutra-dan-penyebaran-islam.html 